\title{
Studenterproduceret video til eksamen
}

- Fokus på samspil mellem læringsdesign og stilladsering

\section{Kenneth Hansen}

\section{E-læringskonsulent}

Arbejder med udvikling og implementering af IKT på tværs af Professionshøjskolen Metropols forskellige uddannelser

\section{Kristian Nøhr Jensen}

\section{E-læringskonsulent}

Arbejder med udvikling og implementering af IKT på tværs af Professionshøjskolen Metropols

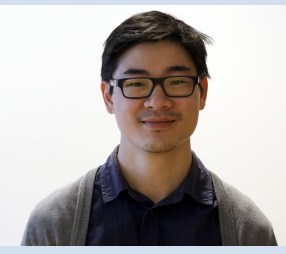
forskellige uddannelser

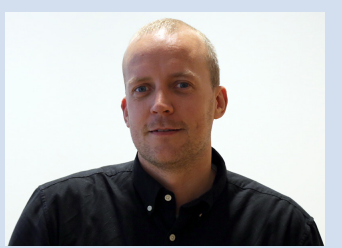




\section{Abstract}

The purpose of this article is to present how learning design and scaffolding can be used to create a framework for student video production for exam purposes at higher educational institutions. The article focuses on issues arising when educational institutions have to handle and coordinate teaching within both the subject matter and media skills. At the same time a balance between the two areas have to be ensured. By dividing the task into several disciplinary resources, more coordination is needed. This issue is dealt with by ensuring that both an educator specialized in media production, and another educator who knows the subject matter, work together on scaffolding the students' progress.

With basis in the perspectives and learning design summarized in the Lanarca Declaration, and primarily on Jerome Brunes' principles of scaffolding, we create a model which can support video productions by students in higher education. By using this model for educational sessions and courses, the subject matter experts and media educators get a tool for focusing and coordinating the effort towards reaching the target of letting students produce and use video for an exam.

\section{Abstract}

Formålet med denne artikel er at vise, hvordan læringsdesign og stilladsering kan anvendes til at skabe en ramme for studenterproduceret video til eksamen på videregående uddannelser. Artiklen tager udgangspunkt i en problemstilling, hvor uddannelsesinstitutionerne skal håndtere og koordinere undervisning inden for både det faglige område og mediefagligt område og sikre en balance mellem en fagfaglighed og en mediefaglig tilgang. Ved at dele opgaven ud på flere faglige resurser, er der mere koordinering, men man kommer omkring problemet med krav til underviserne om dobbelt faglighed ved medieproduktioner.

Med afsæt i Lanarca Declarationens perspektiver på læringsdesign og hovedsageligt Jerome Bruners principper for stilladsering, sammensættes en model for understøttelse af videoproduktion af studerende på videregående uddannelser. Ved at anvende denne model for undervisningssessioner og forløb får de fagfaglige og mediefaglige undervisere et redskab til at fokusere 
og koordinere indsatsen frem mod målet med, at de studerende producerer og anvender video til eksamen.

\section{Indledning}

I denne artikel undersøges det, hvordan man kan give de studerende kompetencer til at anvende video til formidling af faglige problemstillinger til eksamen og dermed trække på både filmfaglige- og fagfaglige kompetencer. Flere videregående uddannelsesinstitutioner eksperimenterer med video som en del af undervisning og eksamen til at skabe en mere alsidig og bedre undervisning (Andreasen, Buhl, Levinsen, \& Ørngreen, 2011; Nørgård, 2004). Fx er der på professionshøjskolen Metropol netop afsluttet flere forløb med op til 1300 studerende, som har skullet aflevere et filmprodukt som udgangspunkt for en mundtlig gruppeeksamen.

Ambitionen om, at de studerende skal producere film, der rammesætter et fagligt indhold, er ikke problemfri. Det afstedkommer en række udfordringer i forhold til, hvordan man i praksis kan klæde både studerende og undervisere på til dette afleveringsformat. Ændringen ved at gå fra traditionelle skriftlige/mundtlige udtryksformer til anvendelse af digitale, multimodale udtryksformer forudsætter en organisering, som understøtter underviserne og de studerende. Teknologiske nyskabelser ændrer det uddannelsesmæssige landskab og medfører sociale og kulturelle forandringer, der præger de måder, hvorpå vi designer undervisning (Kress, 2003). Den digitale teknologi udvider i den sammenhæng de formmæssige udtryksmuligheder, så det $\mathrm{i}$ højere grad bliver muligt at udtrykke sig i andre formater som f.eks. animation, 3D-printning, billede- og videoformater.

At skulle navigere blandt flere udtryksformer stiller nye krav til underviserne, og den multimodale faglighed kan ligge langt fra underviserens specifikke kernefaglighed (Buckingham, 2006, s. 270). Det er undersøgt fx i forbindelse med Digital Kompetence (Ferrari, Punie, \& Redecker, 2012) og Digital Literacy (Echenique, 2015). De ovennævnte eksempler pointerer, at det kan være problematisk, når samme underviser forventes at mestre flere kompetencer, som ligger ud over vedkommendes kernefaglighed. Vi vil derfor anvise en organisering, hvor de fagfaglige og mediefaglige undervisere fokuserer på hvert deres kerneområde i tæt koordination og samarbejde, så de studerende oplever det som et samlet forløb.

Vi ser, at anvendelsen af læringsdesign og stilladsering i samspil kan hjælpe med organisering og tilrettelæggelse af undervisningsforløb. Læringsdesign giver et konkret redskab til planlægning, pædagogisk belæg og mål for undervisningen, mens stilladseringen hjælper med at holde en fælles retning og facilitering gennem læringsprocessen. Dermed iscenesættes en retning mellem det fagfaglige og det mediefaglige og anviser, hvordan og hvornår den 
fagfaglige underviser og medieunderviser kan samarbejde om forløbet, så der skabes de bedste rammer for de studerendes videoproduktion.

I artiklen vil vi først uddybe problemstillingen med krav til dobbelt faglighed hos underviseren, herunder behovet for særlige filmkompetencer. Det gør vi med afsæt i konkrete eksempler fra anvendelse af video til eksamen for 1300 studerende på Professionshøjskolen Metropol. Derefter vil vi udfolde begrebet læringsdesign og komme med en definition på baggrund af litteraturen på området. Vi vil herefter forsøge at knytte Jerome Bruners stilladseringsgreb til anvendelse sammen med læringsdesign. Sidst vil vi præsentere en konkret case, der sætter fokus på behovet for flere kompetencer i forbindelse med faglig undervisning og tilknyttet videoproduktion. Casen eksemplificerer anvendelsesmuligheder i forhold til at bygge et undervisningsforløb op med hjælp af Bruners stilladseringsgreb.

\section{Problematisk med dobbeltfaglige kompetencer hos underviseren}

I universitets- og professionssammenhænge er underviserne typisk fagpersoner, som ikke nødvendigvis besidder større it- og mediekompetence ${ }^{1}$. Det er uproblematisk, så længe de ikke skal varetage flere fagligheder, men det bliver problematisk, når der skal ageres inden for områder, som går ud over deres primære ekspertise (Hofer \& Swan 0, 2008; Mishra \& Koehler, 2008), fx et it-didaktisk eller mediefagligt område.

At opkvalificere underviserne med kompetencer inden for et fagområde som fx medieproduktion er ikke uden problemer og kræver et kompetenceløft af underviserne, der kan vise sig at være både resursekrævende og langsommeligt at løfte i praksis (Bruce \& Chiu, 2015). Der er dog tegn på, at danske uddannelsesinstitutioner er opmærksomme på dette problem, da flere uddannelsesinstitutioner i disse år udbyder en række kurser inden for medier og teknologi, som skal hjælpe til med at opkvalificere underviserne på både universiteter og professionshøjskoler. At institutionen i det hele taget stiller krav til, at der skal produceres video til eksamen, kalder på, at nogen påtager sig ansvaret for, at det rent faktisk er muligt for de studerende at efterleve krav til produktion af video. Dette ansvar peger flere undersøgelser på ikke bare kan skubbes ud til de fagfaglige undervisere, da der ellers vil være risiko for frustration og usikkerhed hos både undervisere og studerende (Møller, 2004; Greener \& Wakefield, 2015; Hofer \& Swan 0, 2008; Bruce \& Chiu, 2015).

\section{Videoproduktioners kvalitet i forhold til at imødekomme det faglige indhold}


Behovet for mediefaglige undervisere bunder i behovet for at sikre en kvalitet i videoproduktionerne, der kan understøtte et fagligt indhold. Videoens kvalitet er i sig selv ikke et mål, men et ringe videoprodukt kan tænkes i værste fald at få negativ indflydelse på formidlingen af det faglige indhold, hvis der $\mathrm{fx}$ anvendes uskarpe billeder, dårlig lyd eller forvirrende klipning. Disse filmfaglige elementer kan indirekte blive udslagsgivende for karakteren. Derfor er der behov for at opkvalificere de studerende med et minimum af mediefaglig kompetence, så de studerendes film understøtter det faglige indhold og som minimum undgår at blive direkte forstyrrende for budskabet.

At der er konkrete krav til at underviserne udfordres i forhold til at skulle mestre kompetencer, som ligger uden for deres fagfaglighed, kan ses i et eksempel med eksamen i faget Tværprofessionalitet på Professionshøjskolen Metropol. Her er udfordringen, at op til 1300 studerende årligt skal aflevere en selvproduceret video af en faglig problemstilling og anvende denne som udgangspunkt for en mundtlig gruppeeksamen. Videoen skal indeholde både en faglig dimension, som den faglige underviser er ansvarlig for, men også en filmfaglig dimension, som inkluderer: at kunne optage, redigere og anvende filmtekniske virkemidler til at præsentere det faglige indhold bedst muligt.

I eksemplet fra Metropol blev der ikke stillet direkte krav til videoens kvalitet, men udelukkende implicitte krav til, at de filmfaglige elementer skulle understøtte det tværfaglige indhold. Det blev vurderet af de ansvarlige for modulet, at de studerende ville have haft store udfordringer uden en eller anden form for støtte fra organisationens side.

\section{Opdelt ansvar og balance mellem fagfaglig og filmfaglig underviser}

I eksemplet med det tværprofessionelle modul på PH Metropol blev det erkendt af uddannelsesplanlæggerne, at de fleste fagfaglige undervisere ikke besad kompetencer inden for både det fagfaglige og det mediefaglige område. Derfor blev det besluttet at holde de to kompetenceområder adskilt, og en opdeling af faglige ansvarsområder blev løsningen til at håndtere kompleksiteten i den nye undervisningssammenhæng. En sådan opdeling ses blandt andet anvendt inden for online undervisning, hvor der ofte skelnes mellem underviseren og facilitatoren. Eksempelvis en opdeling som enten fagfaglig - Subjekt Matter Expert (SME) over for projektleder (Clark, 2002) eller E-moderator over for fagfaglig - underviser (Salmon, 2011). Denne opdeling begrundes med, at inddragelse af teknologi ofte øger kompleksiteten i undervisningssammenhænge.

Der eksisterer desværre ikke meget forskning i, hvordan de to typer underviseres samspil med hinanden faciliteres bedst (Ottestad, Kelentrić, \& Guðmundsdóttir, 2014). En del forskning fokuserer på at undersøge de studerendes digitale kompetencer eller undervisernes færdigheder i et 
videndelingsperspektiv (Bundsgaard, Pettersson, \& Puck, 2014) eller det pædagogiske og faglige udbytte af de studerendes brug af egne videoproduktioner (Andreasen, Buhl, Levinsen, \& Ørngreen, 2011). Den konkrete problemstilling med behovet for at facilitere underviserkompetence inden for de to områder er derfor forholdsvis ubeskrevet.

Ved at tage udgangspunkt i en organisering, som deler ansvaret ud på et fagligt og et mediefagligt ansvarsområde, er det ikke længere nødvendigt at opkvalificere fagfaglige undervisere med mediekundskaber. Til gengæld får man skabt et behov for en grundig koordinering mellem de fagfaglige og de filmfaglige undervisere for at sikre balance mellem det fagfaglige indhold og det filmfaglige i de studerendes produktioner. Uden denne balance riskerer man, at medieunderviseren og de studerende fortaber sig i filmiske detaljer og producerer en film af høj æstetisk og teknisk kvalitet, men uden at kravene til det faglige indhold nødvendigvis opfyldes. Omvendt er der også risiko for, at de studerende med stort fokus på det faglige producerer film, der honorerer de faglige krav, men som ikke understøttes og kvalificeres af det filmiske med risiko for, at det faglige indhold direkte modarbejdes af en filmfaglig ringe kvalitet.

Med den valgte løsning, hvor man opdeler ansvarsområderne mellem en fagfaglig og en mediefaglig underviser står organisationen dermed med følgende problemstilling:

- Hvordan kan man lave konsistente forløb til mange studerende, hvis der skal mange undervisere indover (evt. pga. et stort antal studerende)?

- Hvordan koordineres indsatsen mellem de forskellige undervisere (fagfaglige og mediefaglige)?

- Hvordan sikres en god balance mellem det filmfaglige og det fagfaglige $\mathrm{i}$ de studerendes produktioner?

Med udgangspunkt i disse punkter anvender vi en opdeling i vores læringsdesign med en bevidsthed om, at faglighederne i høj grad skal kobles sammen for at undgå, at de går ud ad hver sin faglige tangent. Vi har valgt at adskille de to typer af undervisere for at skabe optimale rammer for de studerendes arbejde med medieprodukter. Ved at konstruere et parallelforløb mellem medieunderviser og faglig underviser kan hver især fokusere på sit respektive faglige område, og ved at arbejde med Bruners stilladseringsbegreber kan der skabes en ramme til at få sammenhæng og derved undgå frustration og misforståelse med hensyn til retningen i processen.

I forhold til ovenstående problematik og udfordringer vil vi udarbejde et læringsdesign og redegøre for, hvordan den fagfaglige underviser og medieunderviseren sammen kan stilladsere de studerendes filmproduktion, 
så filmens form og indhold understøtter eksamenskravene. Dermed vil vi med artiklen give et svar på:

\section{Hvordan kan vi anvende læringsdesign som rammen for et undervisningsforløb, der stilladserer de studerendes arbejde med at producere en film til eksamen, som balancerer mellem fagfagligt og filmfagligt indhold?}

\section{Beskrivelse af begrebet læringsdesign}

Begrebet læringsdesign består af de to elementer læring og design, som begge beskrives som dynamiske størrelser og genstand for konstant forandring og diskussion (Maina, Craft, \& Mor, 2015) ${ }^{1}$. Nogle forskere og praktikere er meget teknologicentrerede og ser læringsdesign anvendt i en tæt sammenhæng med teknologi, hvor læringsdesign bliver et redskab, der gør det muligt at levere læringsindhold og læringsaktiviteter i forbindelse med computerassisteret læring (Falconer, Finlay, \& Fincher, 2011). Særligt er fokus på at udvikle en form for standard eller software, som kan anvendes til at facilitere læring via digitale platforme (Maina, Craft, \& Mor, 2015).

Andre antager et perspektiv, hvor fokus flyttes fra det teknologicentrerede og over på underviserens rolle i læringsprocesser. Cameron (2009) sætter i artiklen How Learning can illuminate teaching Practice fokus på underviseren og anvender læringsdesign som et refleksionsredskab til egen praksis og forbinder det ikke med det teknologiske perspektiv (Cameron, 2009). Med det perspektiv erkendes det, at der ikke findes én bestemt løsning på design, som mere eller mindre er tanken bag den teknologisk orienterede tilgang, hvor problemer ses som elementer, der blot kan løses rationelt (Holmberg, 2014). At sætte mest fokus på underviserens rolle deles af andre teoretikere inden for feltet, som ser muligheder i at dele læringsdesigns, men pointerer behovet for, at underviseren skal kunne agere kontekstafhængigt inden for læringsdesignets rammer (Dalziel, et al., 2013; Holmberg, 2014).

"While a shared learning design might be used "as is" if it is a
perfect fit for the local context, the usual expectation is that an
educator who adopts a learning design will still need to adapt
it to suit the particular needs of his/her learners. Hence the
re-use of learning design is not a mechanical implementation
process, but rather a creative process where educators use

\footnotetext{
${ }^{1}$ I debatten når man helt ned på grafem-niveau, når der på engelsk, diskuteres om man bør anvende stort eller lille L og D i Learning Design og om aktiviteterne i læringsdesign skal benævnes et læringsdesign eller blot design (Britain, 2004). Hermed kommer selv de mest basale termers betydning i spil når der tales om læringsdesign (Maina, Craft, \& Mor, 2015).
} 


\section{professional judgement to align a good teaching idea from elsewhere with the unique needs of their context"}

(Dalziel, et al., 2013, s. 15).

Uanset perspektiv så tilskrives læringsdesign potentialet til at give underviserne et redskab, der gør dem i stand til at designe både effektive og innovative læringsoplevelser af høj kvalitet til deres elever (Maina, Craft, \& Mor, 2015). Det er lovende potentialer, som til gengæld kræver, at de mange elementer i læringsdesign kan omsættes til praksis. Det ser vi muligt med The Larnaca Declarationen of Learning Design (Dalziel, et al., 2013), som kommer med eksempler på måder at tilgå og anvende læringsdesign, som gør det operationelt og konkret at arbejde med.

Vi er inspireret af perspektiverne i deklarationen, som vi ser som et redskab til at imødekomme vores konkrete udfordringer med at give underviserne et redskab til at understøtte de studerende i processen med at lave film. Dels fordi perspektivet er undervisercentreret og fokus ligger på, hvordan man kan skabe anvendelige repræsentationer for læringsdesign, som hjælper underviserne med at blive explicitte og konkrete i planlægningen af undervisning, så deres designs og refleksioner kan gøres delbare med andre.

En anden vigtig pointe i Larnaca Deklarationen er en idé om, at læringsdesign skal være pædagogisk neutralt (Dalziel, et al., 2013, s. 13), hvilket vil sige, at læringsdesign forholder sig deskriptivt til læring og læringsteori uden at anvise en bestemt læringsteori eller metode som fx konstruktivisme eller Cooperative Learning. Det tolker vi som, at underviserne får frihed til at forme deres praksis inden for rammerne af de læringsdesigns, som deles med dem. Det mener vi kan gøre brugen af læringsdesign yderligere relevant for underviserne i en dansk kontekst, som har didaktisk bevægelsesfrihed og metodefrihed. De vil kunne bruge delte læringsdesigns som et redskab, der giver en høj grad af individuel fleksibilitet i udformning og anvendelse.

Larnaca Deklarationen arbejder med en række modeller, som repræsenterer læringsdesign. Her er vi særligt inspireret af "A Learning Design Conceptual Map", hvori der beskrives en overordnet model for, hvordan de mange elementer af læring og undervisning kan sættes sammen. I forhold til vores konkrete problemstilling ser vi særligt elementet "Level of Granularity", dvs. muligheden for skaléring af læringsdesign, som brugbart. Ud fra denne tanke kan designet modelleres til at indeholde hele programmer og gå helt ned i den enkelte undervisningsaktivitet (Dalziel, et al., 2013, s. 14).

Det er specielt i niveauet mellem "Module og "Learning Activities" (figur 1.), at vi ser et potentiale i forhold til organisering og iscenesættelse af samarbejdet mellem undervisere med forskellige fagligligheder. Konkret i vores case en filmfaglig underviser, som har fokus på formmæsige forhold som æstetik, 
teknik, formidling m.m., over for en fagfaglig underviser, hvor fagets indholdsdimension er essentiel.

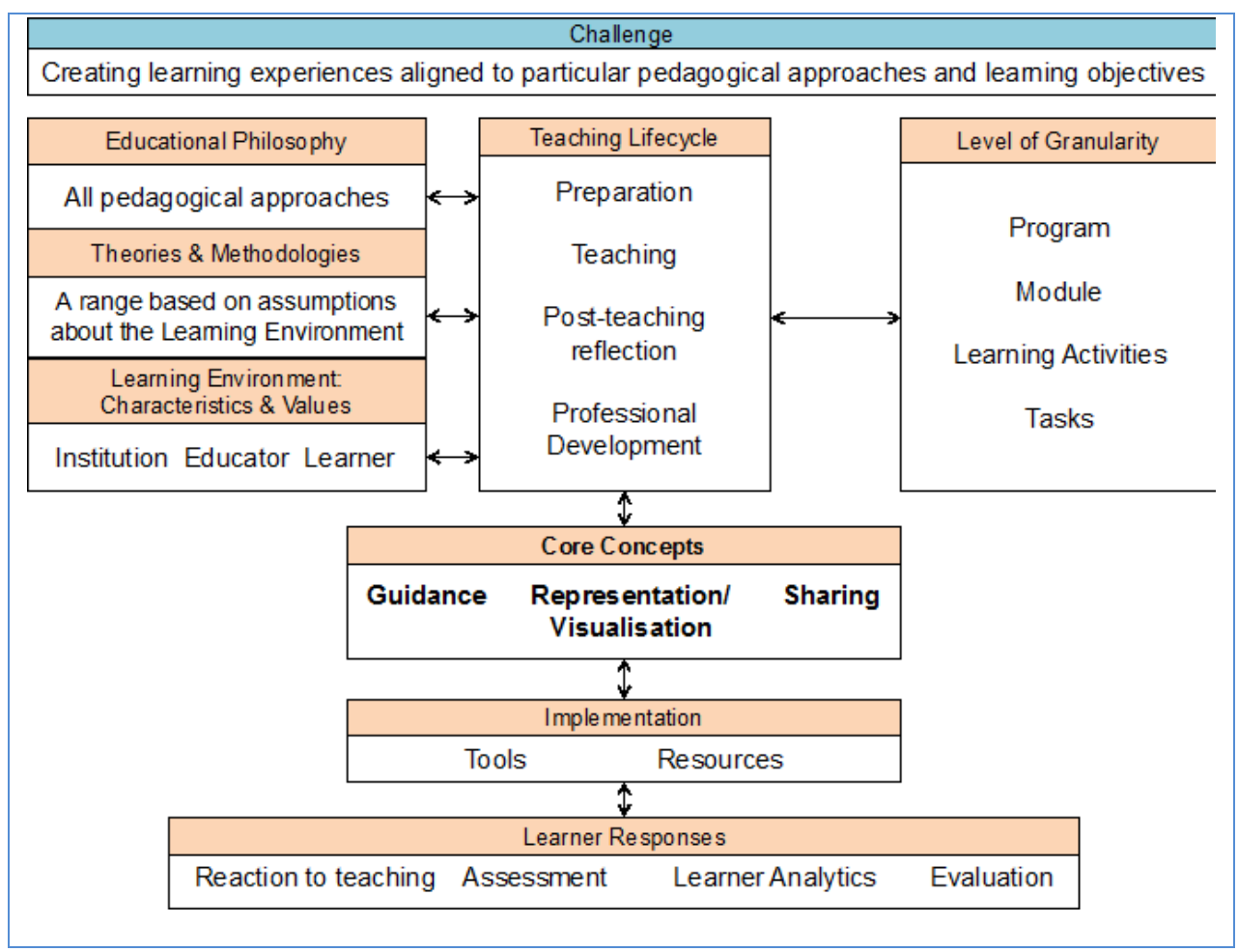

Figur 1: Learning Design - Conceptual Map

Vi har valgt at bruge deklarationens forståelse af læringsdesign i relation til begrebet "stilladsering", hvor vores intention er at give underviserne mulighed for at orientere sig i udvikling af egne forløb parallelt med andres læringsdesign. Desuden hjælper stilladseringsbegrebet til at skabe bevidsthed om udfordringerne ved at anvende og gennemføre læringsdesign i andre kontekster.

Med udgangspunkt i den ovenstående fremstilling af læringsdesign vil vi i denne artikel tage afsæt i en forståelse for læringsdesign, hvor fokus er undervisercentreret (Cameron, 2009) og ikke teknologicentreret, og hvor der med begrebet "læringsdesign" menes en ramme for undervisning og læring gennem eksplicitte refleksioner og planlægning, som gør det muligt at dele designet med andre og lade dem tilpasse det til egen pædagogiske og undervisningsmæssige kontekst (Dalziel, et al., 2013).

\section{Stilladseringsbegrebet ud fra Bruners perspektiv}

Begrebet stilladsering, eller på engelsk - scaffolding, blev oprindeligt introduceret af Bruner, Wood og Ross til forståelse af den lærendes produktion af ny viden (Wood, Bruner, \& Ross, 1976). Begrebet bidrager med en teori om at skabe optimale læringsforudsætninger, hvor den lærendes 
omgivelser giver mulighed for merlæring (Northern Illinois University, 2016; Wood, Bruner, \& Ross, 1976). Begrebet er en hyppigt anvendt term og bruges i mange forskellige uddannelsesmæssige kontekster. Fælles for de forskellige definitioner er, at rammerne, grebene og initiativerne foregår i et kontinuerligt samspil med den lærende imod et mere eller mindre defineret mål (Pinantoan, 2013; Belland, 2013). Hvor begrebet inden for spiludvikling (Weppel, 2015) bliver brugt i sammenhæng med instructional design, ofte med et afsæt i et behavioristisk udgangspunkt (Maina, Craft, \& Mor, 2015), har stilladsering ud fra Jerome Bruner et afsæt $i$, at læring finder sted i en social kontekst med fokus på forhandling af forståelse (Bruner, 1993). I Bruners læringssyn er det ikke kun den kognitive udvikling hos den lærende, men i lige så høj grad omgivelserne omkring den lærende, der bliver italesat. Fokus i Bruners teori om stilladsering går på handlinger i situationer, og det understreges i denne sammenhæng, at læring bliver en gensidig proces mellem forskellige parter (Bruner, 1996). Denne proces indebærer som minimum en "lærer" og en lærende, og læreren behøver ikke nødvendigvis at tænkes i menneskelig forstand, men kan optræde som en genstand i form af en bog eller en computer (Bruner, 1996). Ligeledes påpeges det, at læring godt kan finde sted blandt ligeværdige, når de forskellige parter byder ind med forskellige perspektiver på en problemstilling.

Med Bruners syn på læring samt Wood, Ross og Bruners forståelse af stilladsering bliver det muligt at sætte fokus på at skabe rammerne imod et givent mål (Wood, Bruner, \& Ross, 1976). Stilladsering som begreb giver et sprog til at udfordre underviserrollen samt de organisatoriske greb, der kan iscenesætte mødet med de studerende. Ligeledes ligger der i Bruners teori en anerkendelse af forskellige perspektivers gyldighed frem mod skabelse af fælles viden. Bruner anvender begrebet "oeuvres" (Bruner, 1996), der sætter fokus på den gode samskabelsesproces imod et fælles mål eller produkt. I vores problemstilling bliver det målet, at de studerende bliver i stand til at producere en video, som skal være genstand for en fagfaglig refleksion til eksamen. For at et læringsdesign skal kunne imødekomme en produktion af denne karakter, ser vi det som nødvendigt både at stilladsere de formmæssige udfordringer samt de indholdsmæssige problemstillinger.

Vores fokus ligger på facilitering af samspillet mellem en fagfaglig underviser og medieunderviseren, som skal sikre, at de studerende bliver klædt på til at konstruere et produkt med balance i indholdet fra de to faglige områder. Wood, Ross og Bruners seks overordnede "scaffolding functions" (Wood, Bruner, \& Ross, 1976), hvilket kan oversættes til "stilladseringsgreb". Disse stilladseringsgreb giver i denne sammenhæng et operationelt redskab til at italesætte planlægning og opbygning af et læringsdesign. Eksempler på dette er f.eks. hvor og hvornår de studerende skal informeres (Direction maintenance), i hvilke situationer det er tilstrækkeligt med en overfladisk gennemgang, og hvornår det er vigtigt med et fyldestgørende indblik (Marking 
critical features), og i hvilke tilfælde det er nødvendigt med intens facilitering (frustation control).

- Recruitment: handler om at motivere for opgaven.

- Reduction in degrees of freedom: at gøre opgaven mere eller mindre enkel.

- Direction maintenance: at holde eleven orienteret mod det af læreren fastsatte mål.

- Marking critical features: at pege på, hvad der er det centrale for opgaven.

- Frustration control: at gøre opgaven mere eller mindre frustrerende.

- Demonstration: at demonstrere en løsning, så eleven efterfølgende kan udføre den (Wood, Bruner, \& Ross, 1976).

\section{Iscenesættelse af læringsdesign med Bruners stilladseringsgreb}

I nedenstående afsnit vil vi introducere en model, som gradvist udfoldes, og dermed forsøge at illustrere rammerne for iscenesættelse samt organiseringen af et læringsdesign. Intentionen i modellen er, at underviserne skal kunne støtte de studerende i fremstillingen af et videoprodukt inden for det formmæssige og indholdsmæssige domæne. Ligeledes illustreres det parløb, der skal iscenesættes mellem medieunderviseren og fagpersonen, hvor begges fagligheder anerkendes. Præmissen for dette læringsdesign er, at de forskellige domæner skal understøttes, hvis den studerende skal lykkes med at lave et tilfredsstillende produkt. Med modellen ekspliciteres derfor opbygningen af et modul, hvor den studerende bliver udfordret inden for begge domæner. Målet til en eksamen vil være den film, der bliver produceret af de studerende og som indeholder faglighed fra begge domæner. Den overordnede idé med modellen er dermed at organisere de forskellige fagligheders samspil, der kan understøtte denne udvikling. I denne case, hvor omdrejningspunktet er filmfremstilling, kommer det formmæssige til at udgøre det filmfaglige fokus og indholdet det fagfaglige fokus. Når det vælges i modellen at sætte form over for indhold og ikke filmproduktion over for indhold, er det for at bevare et generisk præg i modellen, så en anden produktionsmæssig kontekst kan bruge modellen til at organisere et forløb.

Efter figur 4 introduceres Bruners stilladseringsgreb som et muligt begrebsapparat til at organisere forløbet fra opstart til eksamen. Stilladseringsgrebene kan bruges til at italesætte de studerendes udfordringer i løbet af forløbet, hvor de både udfordres i deres filmfaglige og fagfaglige fokus. 


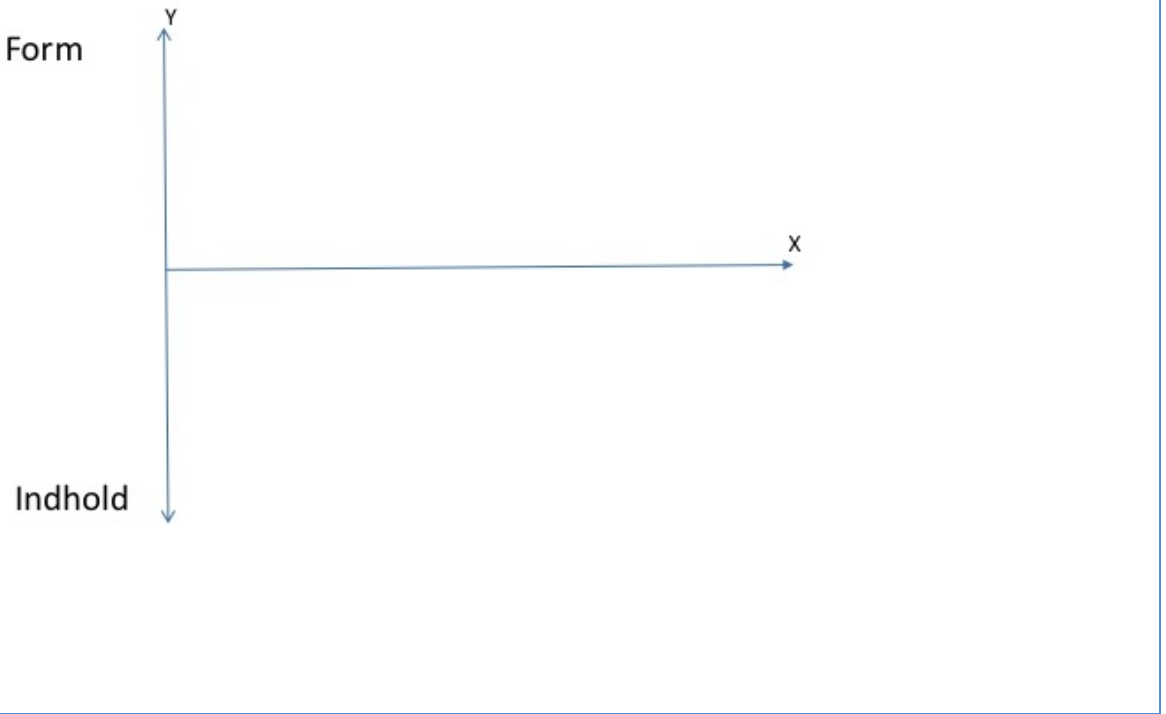

Figur 2: Form og indhold

Overordnet har vi et modsætningspar mellem form og indhold. Begge domæner har en separat faglighed, som det er vigtigt at skelne imellem. Jo længere man begiver sig op (eller ned) ad y-aksen, desto mere adskiller de to fagligheder sig fra hinanden. X-aksen markerer overgangen fra form til indhold. I praksis vil en markant skillelinje af den karakter være omsonst, da der altid vil være overlap - men i dette tilfælde markerer den en overgang, hvor overgangen bliver et værktøj til at italesætte snitfladen mellem de to domæner. 


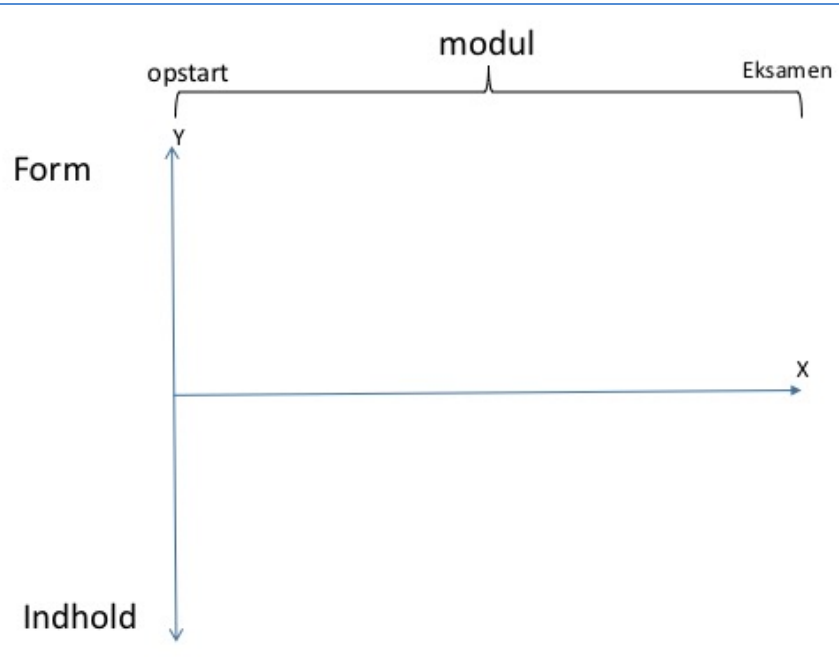

Figur 3: form og indhold frem mod eksamen

Ud ad x-aksen beskrives tid, i dette tilfælde fra starten af modulet til eksamen. Den studerende vil igennem et forløb både møde en faglighed, der har fokus på form, samt en fagfaglig med fokus på et givent indhold. Målet er, at der efter endt forløb er opnået nye kompetencer i mødet med de forskellige fagligheder.

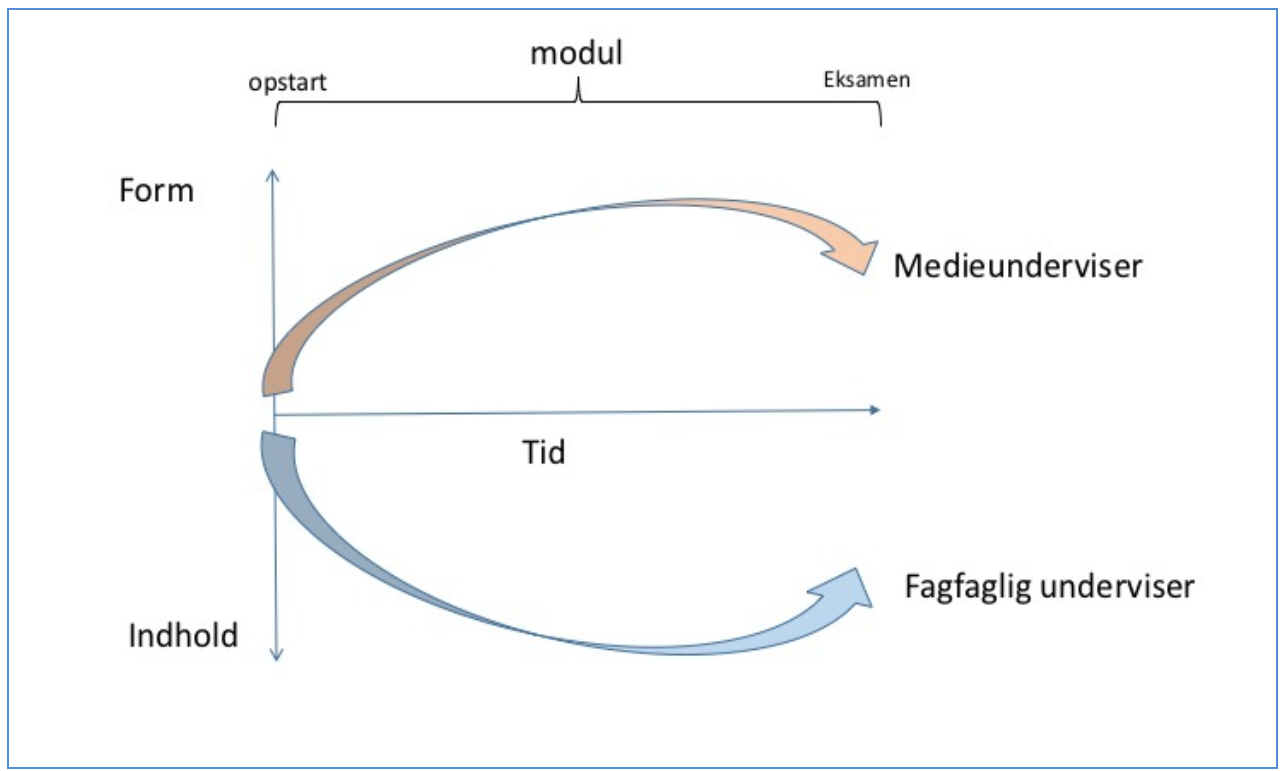

Figur 4: Medieunderviseren og fagfaglig underviser

De to brede pile (medieundervisen/fagfaglig underviser) markerer rammerne samt graden af faglighed. Når modellen åbner, er det for at markere en forventning om, at feltet, hvori de studerende kan agere, udvider sig i takt 
med, at de lærer noget. De to pile viser en intention om, at der sker en faglig udvidelses af feltet, der arbejdes indenfor for de studerende. Dvs. at modellen illustrerer, at undervisere kan introducere materiale og lave læringsaktiviteter for de studerende, men at det er de studerendes ansvar at inddrage og anvende faglighederne fra de forskellige domæner i deres endelige videoproduktion. Jævnfør ovenstående teori om en lærende og en lærer (Bruner, 1996), bruges termerne medieunderviser og fagfaglig underviser til at illustrere de to domæner, der er fokus på. Målet er, at den studerende efter endt forløb har kompetencer til at anvende begge fagligheder i en skabende udfoldelse, i dette tilfælde i produktion af film.

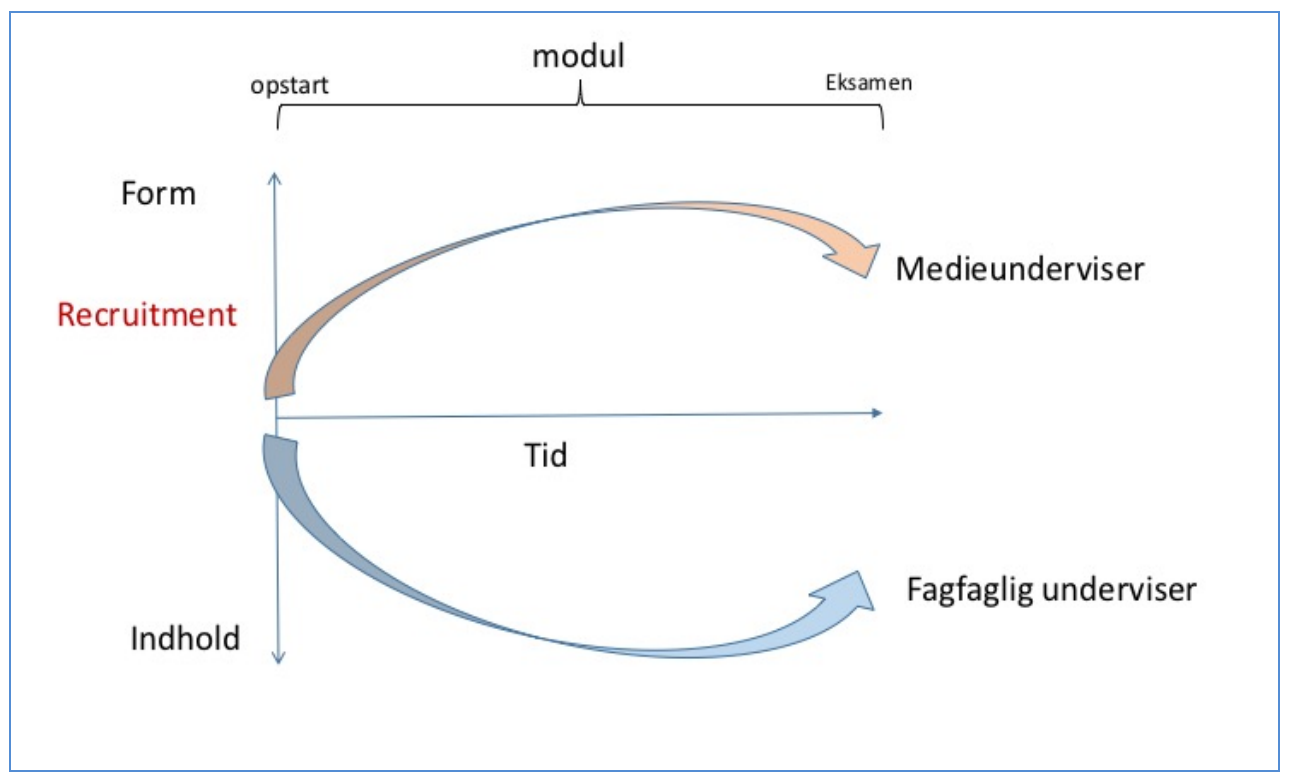

Figur 5: Recruitment

Teorien bag Recruitment kan kort beskrives som motivation i forhold til at løse en given opgave. I Wood Bruner og Ross' beskrivelse af stilladseringsgrebene forklares Recruitment som en selvfølgelighed, at den lærende skal motiveres til at gå i gang. Ligeledes skal problematikken vedrørende løsning af opgaven også forklares for at fastholde motivationen (Wood, Bruner, \& Ross, 1976). I forhold til modellen placeres Recruitment i starten for at signalere den forventningsafstemning, der finder sted, før vi overhovedet begynder på et forløb. En forventningsafstemning, der både er gældende for undervisere og lærende. 


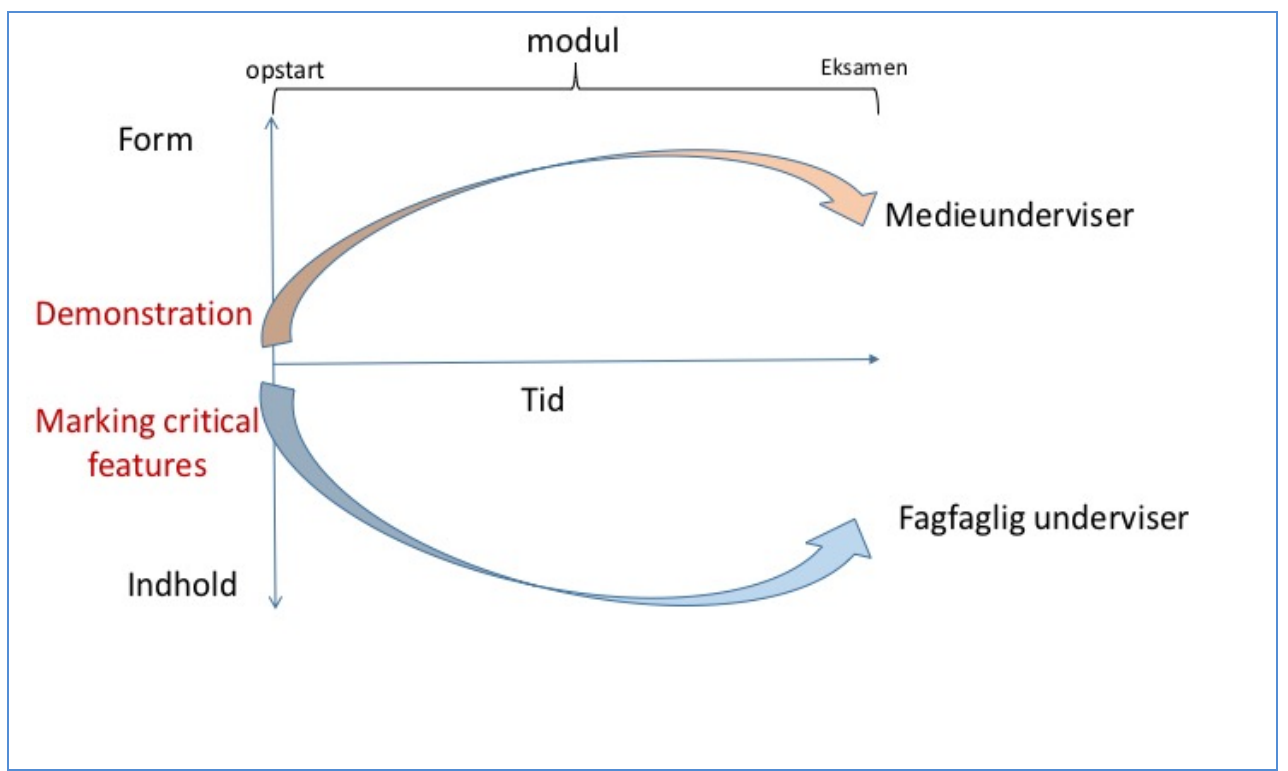

Figur 6: Demonstration og Marking critical features

Opstarten af et modul kan ofte være præget af høj kompleksitet, idet der optræder mange ubekendte faktorer for de studerende: Hvad indeholder modulet? Hvad skal læres? Hvordan bliver jeg målt og vejet? Hvad skal jeg producere? osv.

For at denne proces ikke skaber unødig frustration for de studerende er det essentielt at markere vigtige pointer af modulets indhold. En demonstration af et eksamensprodukt kan i den sammenhæng have afdramatiserende effekt, både i forhold til indholdsperspektivet og ligeledes i forhold til den form, hvormed de skal produceres.

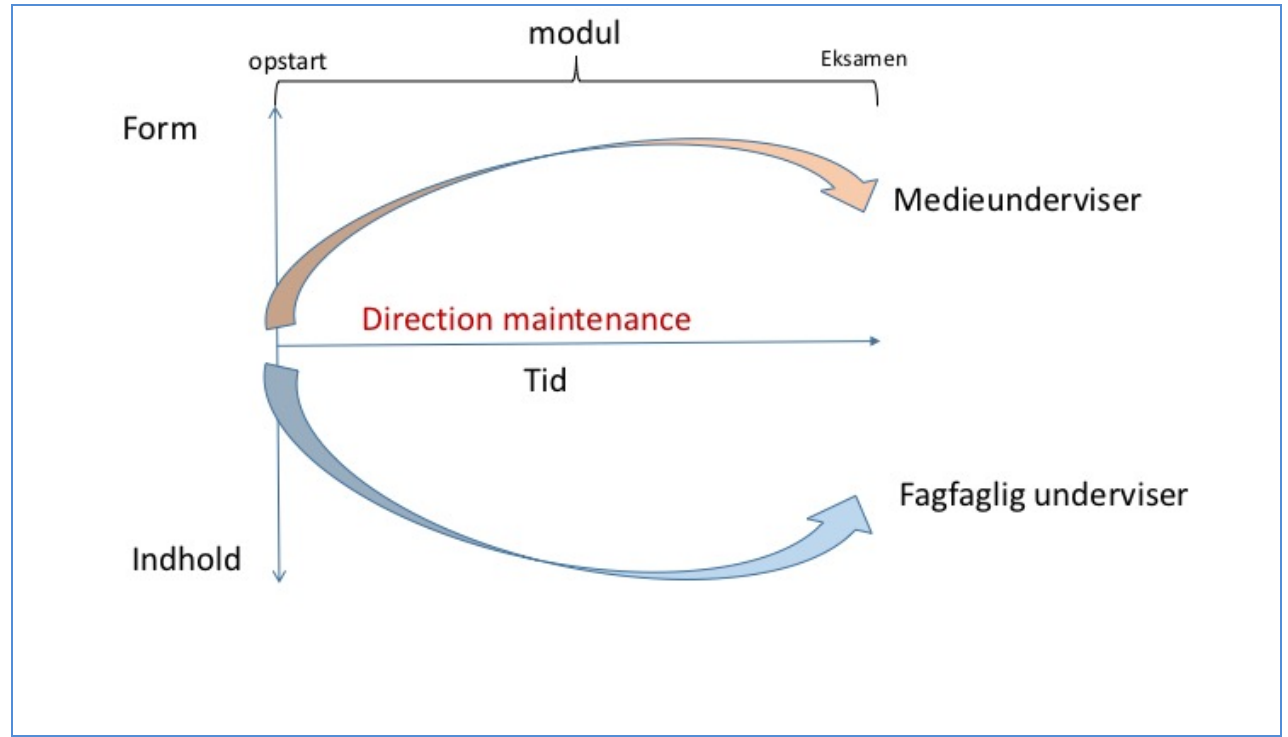

Figur 7: Direction maintenance 
Et element i Bruners læringsteori om stilladsering er idéen om, at den lærende ikke blot skal præsenteres for fakta for at lære, men at læringen er en opdagende og en meningsfuld erkendelse, der opstår i dialog ved inddragelsen af andre perspektiver. Direction maintenance er i denne sammenhæng et fokus på, at vi ikke kan tage for givet, at en faglighed er lært af den studerende efter endt kursus. Begrebet er derfor anvendeligt til at påvise møder med de forskellige fagligheder og skabe dialog med de studerende om, hvor de fagligt befinder sig, og hvor de er på vej hen. Den handler derfor om at eksplicitere eventuelle udfordringer, der kan opstå på de studerendes vej mod det konkrete mål. Udfordinger, der gerne skulle kunne imødekommes af de studerende.

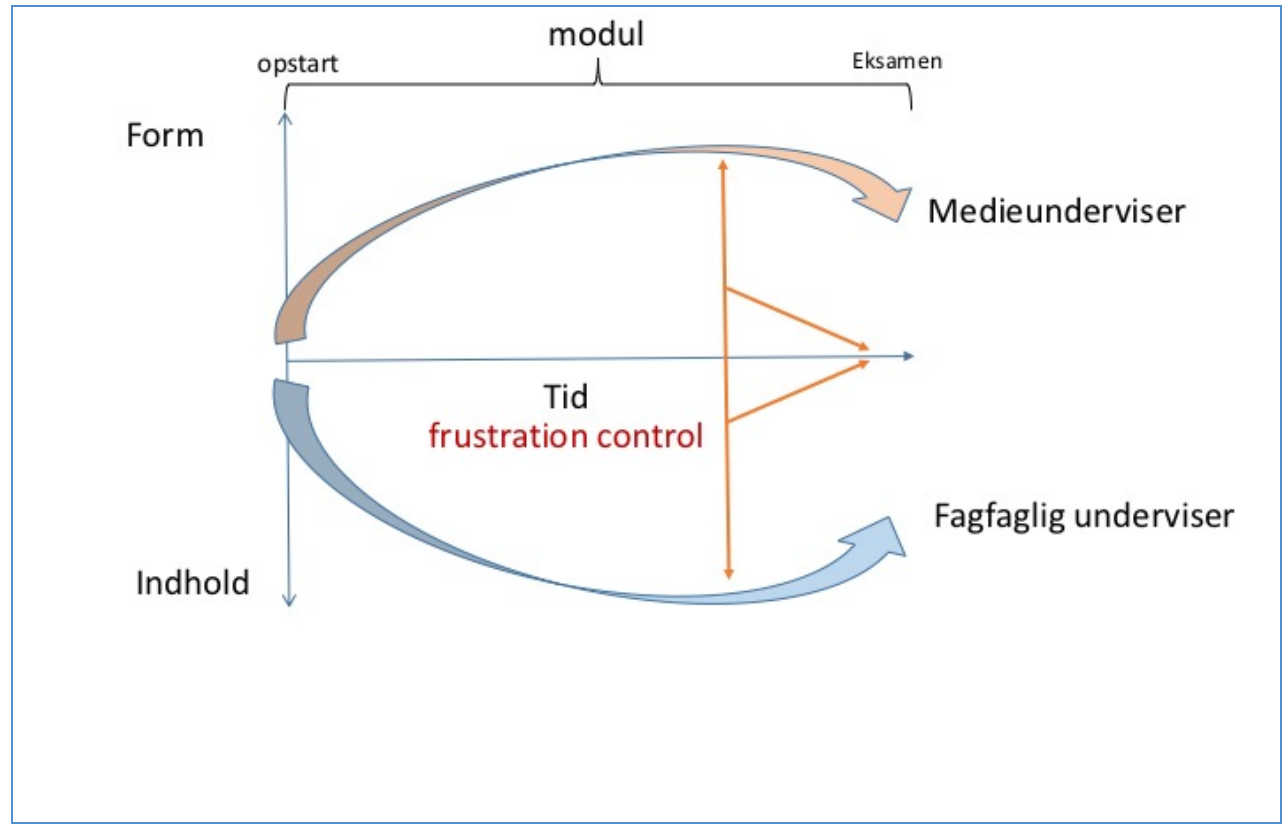

Figur 8: Frustration control

Frustrationskontrol i forhold til stilladsering ligger i en intention om, at opgaven hverken skal være for let eller for kompliceret. Begrebet minder på mange måder om flow (Csikszentmihalyi, 2008), der har fokus på balancen mellem, hvornår en opgave er for simpel eller nærmest kan forårsage stress eller frygt (Csikszentmihalyi, 1996). I modellen vises frustrationskontrol både som en tidslig faktor og som en indholdsmæssig faktor. Tidsfaktoren er vigtig $\mathrm{i}$ forhold til, hvornår det er hensigtsmæssigt, at der optræder ubekendte elementer for den studerende. Jo tættere vi er på eksamen, desto vigtigere er det, at der kun er få ubekendte elementer. Den anden akse illustrerer graden af faglighed. Jo mere fagligt indhold, der bliver introduceret, desto større krav stilles der til de studerendes evne til forstå de forskellige fagligheders relation. F.eks. hvis vi viser, hvordan en hel spillefilm designes, desto større pres kommer der på den studerendes formåen inden for det formmæssige domæne. Omvendt kan der komme et stort fokus på indhold, uden at formen 
berøres, så den studerende ikke ved, hvad det skal ende ud i. Derfor er det vigtigt, at der skabes en vekselvirkning mellem form og indhold for at holde retning mod målet (Csikszentmihalyi, 1996).

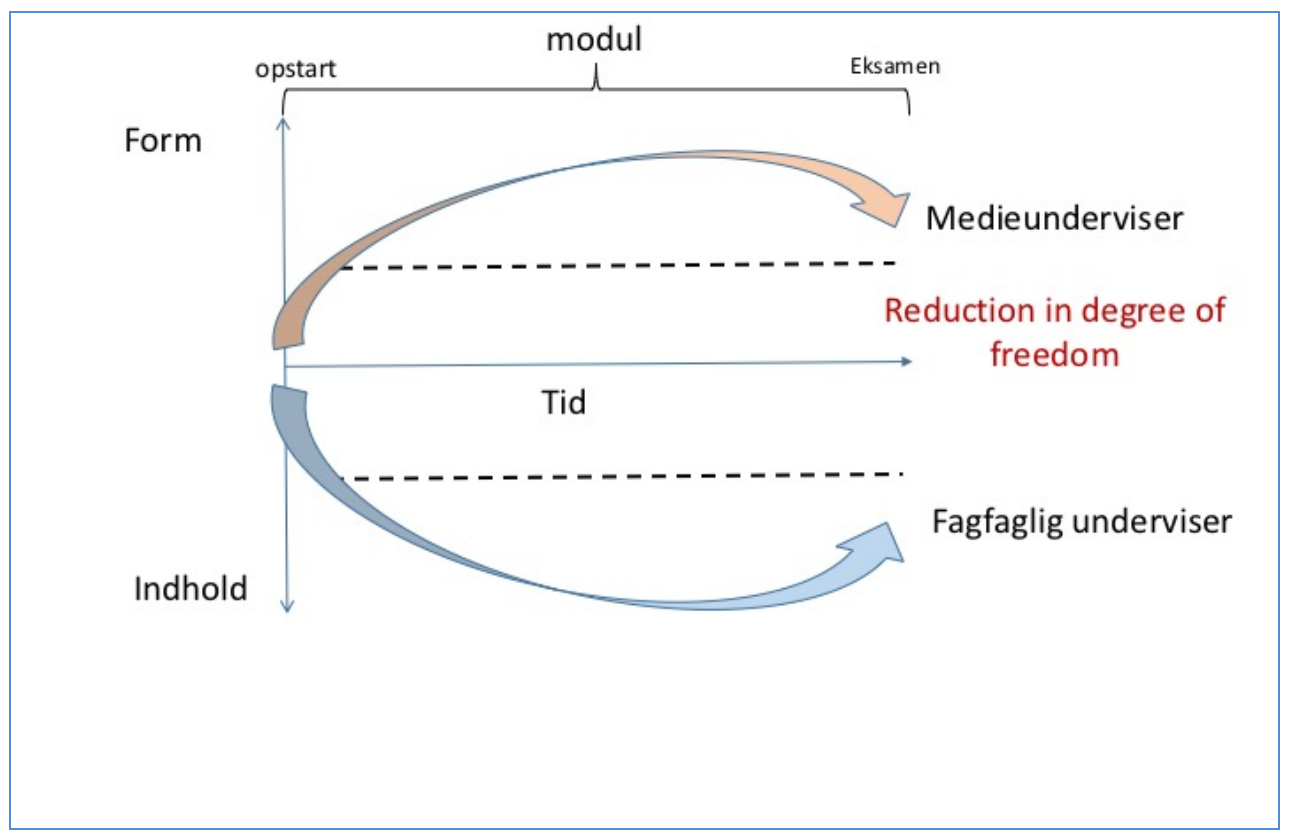

Figur 9: Reduction in degree of freedom

Ved at rammesætte muligheder for, at de studerende kan udfordres tilpas i deres progression, er det centralt at sætte fokus på at skabe en eksplicit ramme, som de studerende kan udfolde sig indenfor. Specielt i forhold til produktets omfang er det vigtigt, at både de formmæssige og de indholdsmæssige krav gøres eksplicitte. I sådan en forventningsafstemning kan der eksempelvis være fokus på produktets længde, teknisk og genremæssige forhold $\mathrm{mm}$.

Bruner identificerer vigtigheden af tilpas frie rammer, hvis den studerende skal være eksplorativt lærende (Bruner, 1961). Disse "tilpas frie rammer" skal igennem forløbet inddrages, så underviseren gør de studerende opmærksom på, hvordan produktet kan iscenesættes som en"Oeuvre" for refleksion til eksamen. 


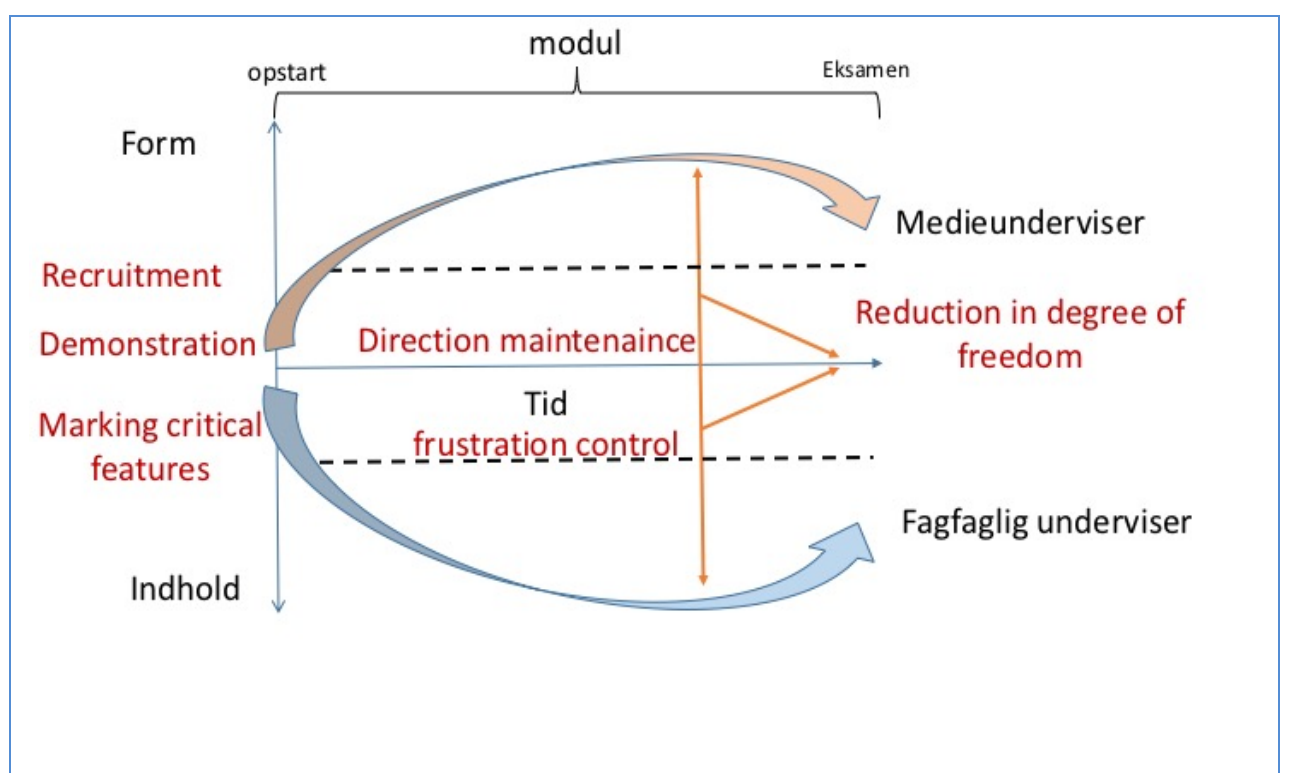

Figur 3: Alle stilladseringsgrebene samlet i forhold til modellen

I denne figur er alle stilladseringsgrebene samlet og viser, hvordan de bidrager i processen mellem form og indhold, mellem medieunderviser og fagfaglig underviser. Stilladseringsgrebene bidrager ydermere til at sætte fokus på organiseringen af et givent indhold over tid. Hvornår er det fx acceptabelt, at de studerende er usikre på målene? Hvornår i forløbet skal de studerende præsenteres for et specifikt indhold? Og ligeledes: hvordan skal de studerende præsenteres for de formmæssige krav.

\section{Intentionen med læringsdesignet}

Hvorfor? - og hvordan? Dette er to essentielle spørgsmål for de undervisere, som skal organisere og facilitere videoundervisning og videoproduktion for studerende i forbindelse med eksamen.

Disse spørgsmål vil vi udfolde i det kommende eksempel på et læringsdesign, som dels skal fungere som redskab til at klæde de studerende på til videoproduktion og samtidig give medieunderviseren et redskab til at reflektere over og få konkretiseret sine planer for undervisning og læring, så andre kan anvende designet på en hensigtsmæssig måde. Vi er inspireret af Larnaca Deklarationen, som, ud over blot at dele sine planer med andre, også giver eksempler på læringsdesign, som lægger vægt på, at underviserne, alt efter erfaring, selv bør kunne handle og være i stand til at justere på indhold og elementer, alt efter behov og kontekst. Derfor har vi forsøgt at skabe transparens i valget af elementer (Learning Activities) og indhold, som gerne skal give underviseren klarhed over hvorfor og hvordan.

Det er med dette læringsdesign intentionen at vise, dels hvordan et læringsdesign kan designes, så det kan understøtte læringsprocessen med at 
skabe film til eksamensbrug fra start til slut, dels give et eksempel på hvordan og hvornår Bruners stilladseringsbegreber konkret kan anvendes til at understøtte og forstærke læringsdesignet.

Intentionen bag designet sker med udgangspunkt i følgende antagelser fra Larnaca Deklarationen, som beskriver, at det primære formål med læringsdesign er:

The ultimate goal of Learning Design is to convey great teaching ideas among educators in order to improve student learning

(Dalziel, et al., 2013).

Vi har dermed et todelt mål for øje, hvor det ene "to convey great teaching ideas" henviser til undervisernes anvendelse, og det andet "improve student learning" har fokus på læringsudbyttet hos de studerende. Valgene til at opfylde disse mål er åbne og kontekstafhængige, alt efter hvor erfaren underviseren er, eller hvor meget de studerende ved om filmproduktion, og hvilke krav der stilles til produktet osv.

Vi har valgt at skabe et læringsdesign, som omfatter fire aktiviteter, hvor den mediefaglige underviser kun har en indirekte rolle i den fjerde. Alle disse valg eller designgreb kan virke banale og er det muligvis også for den erfarne underviser (Holmberg, 2014). Hensigten går på at skabe gennemsigtighed over for de valg og fravalg, som er truffet, og dermed vise og eksemplificere intentionen bag.

Eksempel på læringsaktiviteter, hvor fokus er på de studerendes produktion af video til eksamen

\begin{tabular}{|l}
$\begin{array}{l}\text { Forberedelse } \\
\text { før workshop }\end{array}$ \\
$\begin{array}{l}\text { Afholdelse af } \\
\text { filmworkshop }\end{array}$
\end{tabular} $\begin{aligned} & \text { De studerendes } \\
& \text { filmproduktion }\end{aligned} \quad$\begin{tabular}{l}
$\begin{array}{l}\text { Anvendelse af film } \\
\text { til eksamen }\end{array}$ \\
\hline
\end{tabular}

Figur 11 :Overordnede læringsaktiviteter (Learning Activities) i

læringsdesignet

For at skabe overblik over designet inddeles modulet i fire faser. Imellem disse faser er der yderligere små opgaver (tasks), der binder designet sammen, f.eks. mails, der gør opmærksom på deadlines og andre vigtige forhold. Disse elementer er ikke i fokus i nedenstående forklaring af de fire læringsaktiviteter. 


\section{Forberedelse før workshop}

I den første del, "forberedelse før workshop", er der behov for en forventningsafstemning mellem den faglige underviser og medieunderviseren. Ved dette møde er det meningen at skabe fællesforståelse og forventningsafstemme i forhold til de enkelte underviseres kommende rolle, og hvordan de studerende skal introduceres til de forskellige fagligheder (recruitment).

På dette møde kan man med fordel se eksemplariske videoproduktioner som udgangspunkt for den fælles forståelse. Disse eksempler kan desuden fungere som "Oeuvres" og være retningsanvisning over for begge typer af undervisere og dermed medvirke til at afklare organisatoriske forhold og markere de overordnede rammer og roller i projektet (demonstration).

Intentionen er at forventningsafstemme og være tydelige i, hvad der forventes af den faglige underviser og den mediefaglige underviser. Ved at italesætte mulige udfordringer bliver der på dette forberedelsesmøde også udviklet en forståelse fra underviserne om, hvor de største udfordringer ligger, og hvad de hver især skal være særligt opmærksomme på. I modellen er omdrejningspunktet, hvornår de studerende skal have kontakt med forskellige fagligheder, og i hvilken grad faglighederne skal prioriteres (marking critical features).

\section{Afholdelse af filmworkshop}

Denne aktivitet foregår inden for det formmæssige domæne, og medieunderviseren er den primære aktør. Meningen er at klæde de studerende på med relativt begrænsede resurser til efterfølgende selv at producere video, som har både faglige, æstetiske og kommunikative kvaliteter, der kan anvendes til deres eksamen. I forhold til modellen, hvor feltet åbnes for de studerende, optræder mange ubekendte faktorer, der skal imødekommes af medieunderviseren. I den sammenhæng er det vigtigt at gøre de studerende opmærksomme på minimumskrav til produktet (marking critical features).

Intentionen er, at de studerende i løbet af denne workshop får faglig inspiration (recruitment) til at arbejde med videoproduktion. D.v.s. viden og færdigheder til at arbejde med de mediefaglige områder helt ned på værktøjsniveau, hvor specifikke redskaber til at filme og redigere udfoldes. I denne proces, før den kommende filmproduktion og filmredigering, er det vigtigt at guide de studerendes produktion, så den ikke fortaber sig i hverken ren faglighed eller i ren legen rundt i filmmediet (direction maintenance). Ved at skabe opmærksomhed på faldgruber og udfordringer i den videregående proces er målet, at de studerende selvstændigt skal imødekomme de filmiske krav. 


\section{De studerendes filmproduktion}

I denne aktivitet er det den fagfaglige underviser, som er sammen med de studerende under deres videoproduktion og som bidrager med fagligt input. Medieunderviseren er ikke tilstede til at imødekomme praktiske og tekniske problemstillinger. Der kan med fordel planlægges spørgesession, hvor medieunderviseren stiller sig til rådighed i forhold til opsamlede problemstillinger (frustration control).

Løbende har de studerende adgang til online materiale, som er produceret eller udvalgt af medieunderviseren, og som dækker indholdet fra workshoppen. Der vil også være adgang til eksemplariske film, som de studerende kan lade sig inspirere af.

\section{Anvendelse af film til eksamen}

Målet for hele forløbet er, at filmen skal fungere som art "Oeuvre", altså som udgangspunkt for en fagfaglig samtale. At de studerende har fået produceret en film med høje filmiske kvaliteter, som kan underbygge deres faglige pointer. På dette tidspunkt er det den studerende, der skal vise tillærte færdigheder, og den fagfaglige underviser, som skal kvalitetssikre og styre processen. Intentionen er, at den faglige underviser ikke skal bedømme de filmiske kvaliteter, men elementer som dårlig lyd, kameraføring, manglende narrativ kan medvirke til, at budskaberne og fokusområder ikke fremstilles skarpt.

Målet er, at de fire læringsaktiviteter i læringsdesignet kan anvendes som beskrevet eller modificeres efter behov. Andre kontekster har måske studerende, som tidligere har arbejdet med film og derfor ikke behøver workshopdelen. Andre har faglige undervisere, som måske også er kompetente medieundervisere og derfor kan varetage begge roller og dermed ikke behøver forberedelse før filmworkshopdelen.

\section{Eksempel på læringsdesignets indhold, hvor læringsaktiviteter} er vist i skematisk form for at give et hurtigt overblik

I tabelform kan forløbet få et mere systematiseret udtryk. Nedenfor er de fire læringsaktiviteter beskrevet over for de potentielle stilladseringsgreb.

\begin{tabular}{|l|l|l|}
\hline $\begin{array}{l}\text { Læringsktivitens } \\
\text { formål }\end{array}$ & Indhold & Stilladsering \\
\hline $\begin{array}{l}\text { Forberedelse før } \\
\text { filmworkshop }\end{array}$ & $\begin{array}{l}\text { Fælles møde mellem } \\
\text { fagfaglig underviser } \\
\text { og medieunderviser. }\end{array}$ & $\begin{array}{l}\text { I dette første møde } \\
\text { afklarers } \\
\text { forventningerne til } \\
\text { rollerne Direction } \\
\text { maintanance i } \\
\text { arbejdet med form } \\
\text { og indhold. }\end{array}$ \\
$\begin{array}{l}\text { Formålet er at } \\
\text { skabe fælles } \\
\text { forståelse for } \\
\text { projektet og den } \\
\text { endelige opgave } \\
\text { mellem faglig }\end{array}$ & & Der vises \\
\hline
\end{tabular}




\begin{tabular}{|c|c|c|}
\hline $\begin{array}{l}\text { underviser og } \\
\text { medieunderviser. }\end{array}$ & & $\begin{array}{l}\text { Demonstration af } \\
\text { produkter og } \\
\text { pointeres kritiske } \\
\text { områder, hvor der } \\
\text { kan opstå problemer } \\
\text { og misforståelser. } \\
\text { Herved sørges der } \\
\text { for, at der ikke } \\
\text { opstår for stort gab } \\
\text { mellem de to } \\
\text { fagligheder } \\
\text { Reduction in } \\
\text { degree of freedom. }\end{array}$ \\
\hline $\begin{array}{l}\text { Formålet er at } \\
\text { mindske } \\
\text { frustrationer og } \\
\text { afdramatisere den } \\
\text { kommende } \\
\text { eksamen hos de } \\
\text { studerende. }\end{array}$ & $\begin{array}{l}\text { Medieunderviser og } \\
\text { fagfaglig underviser } \\
\text { gør materialer } \\
\text { tilgængelige for } \\
\text { studerende online. I } \\
\text { god tiden inden } \\
\text { afholdelse af } \\
\text { filmworkshop. }\end{array}$ & $\begin{array}{l}\text { Ved at gøre } \\
\text { eksemplarer og } \\
\text { materiale } \\
\text { tilgængeligt for de } \\
\text { studerende anvendes } \\
\text { Demonstration og } \\
\text { Frustration Control. }\end{array}$ \\
\hline $\begin{array}{l}\begin{array}{l}\text { Afholdelse af } \\
\text { filmworkshop }\end{array} \\
\text { Formålet er at } \\
\text { klæde de } \\
\text { studerende på til at } \\
\text { skabe } \\
\text { filmprodukter med } \\
\text { højt filmfagligt } \\
\text { indhold, som kan } \\
\text { understøtte det } \\
\text { fagfaglige. }\end{array}$ & $\begin{array}{l}\text { Medieunderviser } \\
\text { afholder workshop for } \\
\text { de studerende. } \\
\text { Den fagfaglig } \\
\text { underviser kan } \\
\text { deltage, men er ikke } \\
\text { nødvendig. }\end{array}$ & $\begin{array}{l}\text { I løbet af denne } \\
\text { workshop får de } \\
\text { studerende styr på } \\
\text { området mellem } \\
\text { fagfaglighed og } \\
\text { filmfaglighed } \\
\text { Reduction in } \\
\text { degree of freedom. } \\
\text { Ved at se } \\
\text { demonstrationer } \\
\text { anvises Direction of } \\
\text { maintanance. } \\
\text { Ved at give en } \\
\text { Demonstration } \\
\text { afdramatiseres det } \\
\text { ellers komplekse. } \\
\text { Inden for det } \\
\text { filmfaglige påpeges } \\
\text { udvalgte gode råd til } \\
\text { at skabe et bedre } \\
\text { filmprodukt } \\
\text { Marking of Critical } \\
\text { features. } \\
\text { Endelig udøves } \\
\text { Frustration Control, } \\
\text { fordi }\end{array}$ \\
\hline
\end{tabular}




\begin{tabular}{|c|c|c|}
\hline & & $\begin{array}{l}\text { medieunderviseren } \\
\text { er tilstede og kan } \\
\text { afhjælpe omgående. }\end{array}$ \\
\hline $\begin{array}{l}\text { Filmproduktion } \\
\text { Formålet med disse } \\
\text { tips er at huske de } \\
\text { studerende på de } \\
\text { vigtigste pointer. }\end{array}$ & $\begin{array}{l}\text { Kort før selve } \\
\text { produktionen af film } \\
\text { gives tips til de } \\
\text { studerende i forhold } \\
\text { til deres drejebog og } \\
\text { film. }\end{array}$ & $\begin{array}{l}\text { Marking of Critical } \\
\text { Features, både i } \\
\text { forhold til } \\
\text { filmproduktion og i } \\
\text { forhold til et } \\
\text { fagfagligt indhold. }\end{array}$ \\
\hline $\begin{array}{l}\text { Formålet er, at de } \\
\text { studerende kan } \\
\text { anvende den faglige } \\
\text { viden i } \\
\text { sammenhæng med } \\
\text { den filmfaglige, så } \\
\text { der skabes et } \\
\text { indhold, hvor form } \\
\text { og indhold er i } \\
\text { balance. }\end{array}$ & $\begin{array}{l}\text { De studerende } \\
\text { producerer film i } \\
\text { deres gruppe. } \\
\text { Der er mulighed for } \\
\text { hjælp til } \\
\text { videoproduktionen fra } \\
\text { medieunderviseren } \\
\text { ved en fysisk } \\
\text { spørgetime og via en } \\
\text { række videoguides. } \\
\text { Der er mulighed for } \\
\text { fagfaglig hjælp fra den } \\
\text { faglige underviser. }\end{array}$ & $\begin{array}{l}\text { Denne fase er præget } \\
\text { af stor grad af } \\
\text { Frustration Control, } \\
\text { som bæres igennem } \\
\text { af den direkte } \\
\text { kontakt eller via det } \\
\text { tilgængelige online } \\
\text { eksemplariske } \\
\text { materiale } \\
\text { Demonstration med } \\
\text { både teknisk hjælp } \\
\text { og eksempler på film } \\
\text { i den faglige } \\
\text { kontekst. }\end{array}$ \\
\hline $\begin{array}{l}\text { Anvendelse af film } \\
\text { til eksamen } \\
\text { Formålet er at } \\
\text { præsentere et } \\
\text { videoprodukt } \\
\text { (oeuvres) til } \\
\text { eksamen, som } \\
\text { leverer et fagligt } \\
\text { indhold, som er } \\
\text { understøttet af den } \\
\text { filmfaglige form. }\end{array}$ & $\begin{array}{l}\text { Filmen anvendes i } \\
\text { eksamenssituationen } \\
\text { med faglig underviser. } \\
\text { Medieunderviser er } \\
\text { helt ude i denne del. }\end{array}$ & $\begin{array}{l}\text { Hele forløbet skulle } \\
\text { gerne munde ud i, at } \\
\text { den faglige } \\
\text { underviser } \\
\text { udelukkende kan } \\
\text { koncentrere sig om } \\
\text { at vurdere filmen ud } \\
\text { fra det faglige } \\
\text { indhold, som gerne } \\
\text { skal være } \\
\text { understøttet af det } \\
\text { filmfaglige. }\end{array}$ \\
\hline
\end{tabular}

Læringsdesignet kan beskrives yderligere og eksempelsvis tilføjes en beskrevet plan for de forskellige læringsaktiviteter, og disse aktiviteter kan, alt efter kompleksitet, også udfoldes og beskrives yderligere i detaljen. 


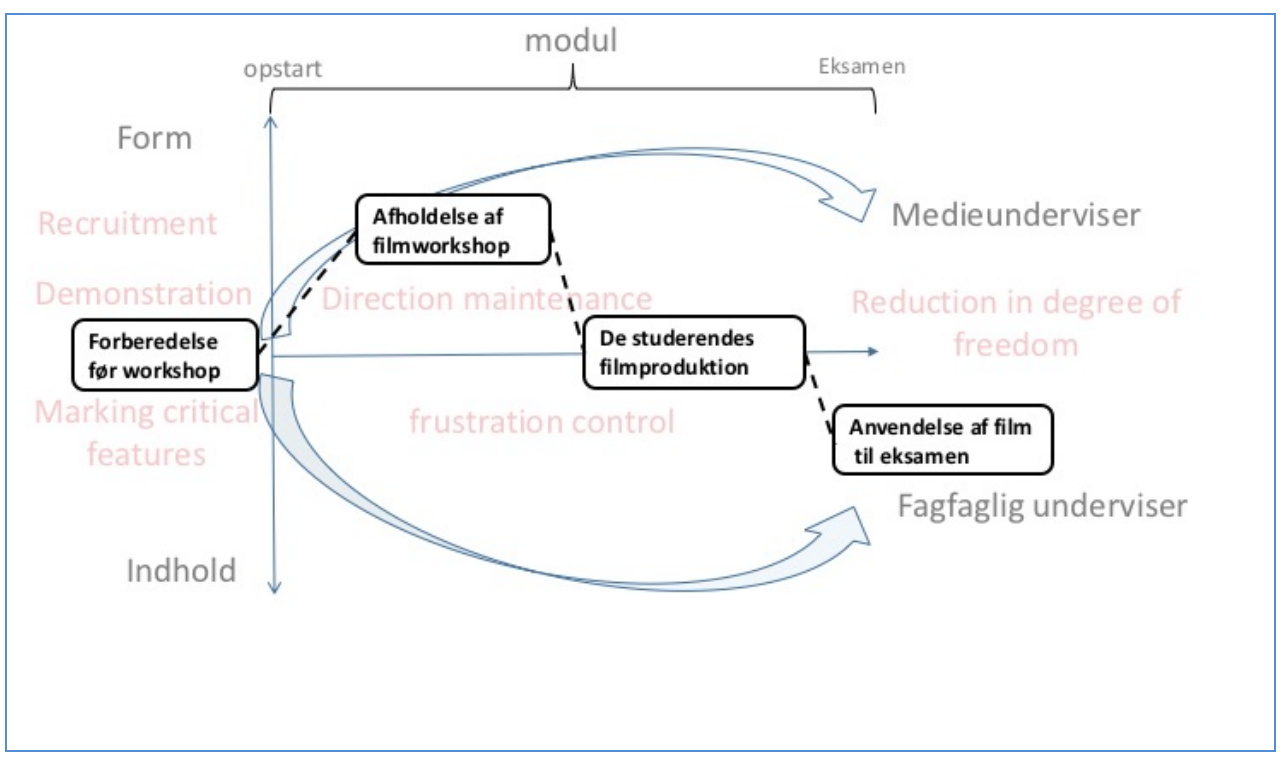

Figur 12: Organiseringen af modellen i forhold til læringsaktiviteternes fokus.

For at opsummere hvordan vi ser Bruners stilladseringsgreb anvendt $\mathrm{i}$ læringsdesignet, er læringsaktiviteterne vist hen over modellen for derved at vise, hvor fokus er for de forskellige aktiviteter. Når "anvendelse af film til eksamen" ligger i det indholdsmæssige domæne, er det, fordi produktet skal fungere som fagfagligt udgangspunkt (Oeuvres) til eksamen.

\section{Konklusion}

Vi har med denne artikel forsøgt at vise en mulig vej, når der skal arbejdes med videoproduktion til eksamen på højere uddannelsesinstitutioner. At der stilles krav til videoproduktion, stiller samtidig krav til de studerendes videoproduktionskompetencer, som igen stiller krav til underviserne om at besidde mediekompetencer ud over deres kernefaglighed. Hvis dette ikke er muligt, må de fagfaglige undervisere skulle støtte sig til medieundervisere og i fælleskab få koordineret en indsats, som understøtter målet med at få skabt videoer med fagligt indhold. Det stiller en række krav til en organisering, som formår at rumme de behov, som opstår i forbindelse med krav om videoproduktion.

Vi foreslår at anvende en række principper for læringsdesign og knytte dem an til Bruners stilladseringsgreb. De anvendte principper for læringsdesign tilstræber at give underviserne frihed til tilpasning af personlig undervisningsstil og kontekst, men som samtidig bevarer en vis ensartethed $\mathrm{i}$ alle forløb ved at skabe gennemsigtighed i de pædagogiske og didaktiske refleksioner og den praktiske planlægning af undervisningens elementer. Der skabes med Learning Design - Conceptual Map en rød tråd gennem hele 
forløbet, som kan gå fra den overordnede plan for hele modulet og ned til en enkelt undervisningsaktivitet i en session.

Vi har i forbindelse med udviklingen af vores læringsdesign anvendt en række af Bruners stilladseringsgreb til at skabe en ramme for læringsdesignet, der giver en retning i forløbet med balance mellem det filmfaglige og det fagfaglige indhold. Samtidig understøttes de to fagligheders koordinering, tidspunkt for handlen samt udpeger de kritiske tidspunkter i den samlede proces, hvor der kræves et ekstra fokus for at undgå frustration.

Samlet set vil læringsdesignet understøtte en proces, hvor underviserne hjælper de studerende med at producere video til deres eksamen med fokus på det faglige indhold.

\section{Hvordan kan dette læringsdesign bruges af andre?}

Vi har beskrevet en tilgang til læringsdesign, anvendt i relation med stilladsering, som gør det legitimt for den faglige underviser primært at fokusere på den faglige del, idet undervisningen i video og tekniske aspekter varetages af andre fagligheder. Designet anviser i den forbindelse, hvor og hvordan det er givtigt for de to underviserroller at mødes og skabe sammenhæng i bestræbelsen på at skabe balance mellem form og indhold.

Ved at anvende den beskrevne tilgang til læringsdesign vil man på de videregående uddannelser kunne levere undervisning i anvendelse af video til både mindre og til store grupper af studerende i høj kvalitet. En kvalitet, som sikres gennem stilladsering og velgennemtænkte læringsdesigns, som indeholder så meget gennemsigtighed, at de individuelle institutioner og undervisergrupper vil kunne anvende læringsdesignet direkte eller have let ved at tilpasse det til egen kontekst.

Bruners begreber om stilladsering bliver i forbindelse med teorierne for læringsdesign anvendt som et yderligere lag, der kan guide underviser og studerende i læringsprocessen. I et helt overordnet perspektiv kan der argumenteres for, at læringsdesignet og stilladseringen kan anvendes med andre medier end video. F.eks. gamification, lydoptagelser og animation m.m. I disse opsætninger vil der igen være behov for rammesætning med specialister med alt, hvad det inkluderer af organisering og struktur.

\section{Referencer}

Andreasen, L. B., Buhl, M., Levinsen, K., \& Ørngreen, R. (2011).

Videoproduktioner som læringsressource i universitetsundervisning. I

B. Meyer, It-didaktisk design - Cursiv nr. 8 (s. 59-83). Aarhus Universitet. 
Belland, B. R. (2013). Scaffolding: Definition, Current Debates, and Future Directions. I J. Spector, M. Merrill, J. Elen, \& M. Bishop, Handbook of Research on Educational Communications and Technology (s. 505-518). Springer.

Britain, S. (2004). A Review of Learning Design - Concept, Specifications and Tools. A report for the JISC E-learning Pedagogy Programme.

Bruce, D. L., \& Chiu, M. M. (2015). Composing With New Technology Teacher Reflections on Learning Digital. Journal of Teacher Education, s. 272-287.

Bruner, J. (1961). The Act of Discovery. Harvard Educational Review, s. 2132.

Bruner, J. (1993). Acts of Meaning. Harvard University Press.

Bruner, J. (1996). The Culture of Education. Harvard University Press.

Buckingham, D. (2006). Defining digital literacy - What do young people need to know about digital media? Digital Kompetense Vol. 1, s. 263-276.

Bundsgaard, J., Pettersson, M., \& Puck, R. M. (2014). Digitale kompetencer It i danske skoler i et internationalt perspektiv.

Cameron, L. (2009). How learning design can illuminate teaching pratice. The Future of Learning Design Conference Paper 3., s. 20-27. Hentet fra http://ro.uow.edu.au.

Clark, D. (2002). Psychological myths in e-learning. Med.Teach, s. 598-604.

Csikszentmihalyi, M. (1996). Creativity: Flow and the psychology of discovery and invention. Harper and Collins.

Csikszentmihalyi, M. (2008). Selvets udvikling -evolution, flow og det gode samfund. Dansk psykologisk Forlag.

Dalziel, J., Conole, G., Wills, S., Walker, S., Bennett, S., Dobozy, E., ... Bower, M. (2013). The Larnaca Declaration on Learning Design. Hentet fra The Larnaca Declaration on Learning Design: http://www.larnacadeclaration.org/

Falconer, I., Finlay, J., \& Fincher, S. (2011). Representing Practice: practice models, patterns, bundles. Media and Technology, Vol. 36, No. 2, s. 101127.

Ferrari, A., Punie, Y., \& Redecker, C. (2012). Digital Competence in Practice: An Analysis of Frameworks. Luxembourg: Publications Office of the European Union.

Greener, S., \& Wakefield, C. (2015). Developing Confidence in the Use of Digital Tools in Teaching. Electronic Journal of e-Learning, v13 n4, s. 260267. 
Hofer, M., \& Swan O, K. (2008). Technological Pedagogical Content Knowledge in Action: A Case Study of a Middle School Digital Documentary Project. Journal of Research on Technology in Education (International Society for Technology in Education), s. 179-200.

Holmberg, J. (2014). Studying the process of educational design - revisiting Schön and making a case for reflective design-based research on teachers' 'conversations with situations'. Technology, Pedagogy and Education Vol. 23, No. 3, s. 293-310.

Kress, G. (2003). Literacy in the New Media Age. London: Routledge.

Maina, M., Craft, B., \& Mor, Y. (2015). The Art \& Science of Learning Design. Rotterdam: Sense Publishers.

Mishra, P., \& Koehler, M. J. (2008). Introducing Technological Pedagogical Content Knowledge. I I. T. Technology, The Handbook of Technological Pedagogical Content Knowledge forTeaching and Teacher Educators (s. 329). New York \& London: Routledge.

Møller, A. (2004). Den kompetente netunderviser - underviserkompetencer i det virtuelle læringsmiljø. Tidsskrift for universiteternes efter- og videreuddannelse, 1. årgang, nr. 4, 2004.

Northern Illinois University. (2016). Instructional Scaffolding to Improve Learning. Hentet fra http://www.niu.edu: http://www.niu.edu/facdev/resources/guide/strategies/instructional_ scaffolding_to_improve_learning.pdf

Nørgård, C. F.-J. (2004). Digitalisering af færdighedstræning og laboratorieøvelser. Tidsskriftet Læring og Medier (LOM).

Ottestad, G., Kelentrić, M., \& Guðmundsdóttir, G. B. (2014). Professional Digital Competence in Teacher Education. Nordic Journal of Digital Literacy Vol. 9 nr. 4-2014, s. 244-249.

Pinantoan, A. (2013). Inform Ed. Hentet fra Instructional Scaffolding: A Definitive Guide: http://www.opencolleges.edu.au/informed/teacherresources/scaffolding-in-education-a-definitive-guide/

Salmon, G. (2011). Emoderating - The key to teaching and learning online. New York: Routledge.

Weppel, S. D. (2015). gpstrategies.com. Hentet fra The Design of Scaffolding in Game-based Learning: A Formative Evaluation: http://www.gpstrategies.com/astd2014/docs/wpScaffolding.pdf

Wood, D., Bruner, J. S., \& Ross, G. (1976). The role of tutoring in problem solving. Journal of child psychology and psychiatry, Oxford New York: Pergamon Press, s. 89-100. 


\section{Noter}

1 På Københavns Universitet har man eksempelvis søsat projekt Online og Blended Learning som tilbyder underviserne kurser og vejledning i alt fra anvendelse af digitale afstemningsredskaber til anvendelse af digitale quizzer. På Syddansk Universitet udbydes en række kurser, rettet imod undervisere som skal kompetenceløftes indenfor e-learning og andre it-baserede redskaber. Aarhus Universitet, har en plan for Educational IT, som skal løfte undervisernes digitale kompetencer.

Professionshøjskolen Metropol har med sin 2020 plan lagt mål for udvikling af digital læring, som skal sikre at uddannelsen i tilstrækkelig grad inddrager it som del af undervisningen, og i denne plan indgår også et friviligt it- kompetenceløft af underviserne . 